\title{
STRATEGI PENGUATAN KARAKTER RASA INGIN TAHU PADA PESERTA DIDIK MELALUI PEMBELAJARAN SAINTIFIK DI SD CENDEKIA ISLAMIC SCHOOL KELAS IV
}

\author{
Reksa Adya Pribadi ${ }^{1}$, Dea Mahdayana ${ }^{2}$, Zhaffa Ramadhani Zahra ${ }^{3}$ \\ ${ }^{123}$ PGSD Fakultas Keguruan dan IImu Pendidikan, Universitas Sultan Ageng \\ Tirtayasa \\ reksapribadi@untirta.ac.id, 2227190100@untirta.ac.id, 2227190057@untirta.ac.id
}

\begin{abstract}
This study aims to determine the strategy of strengthening curiosity as a trait using a scientific approach. The population of the study is among the 4th-grade students of SD Cendekia Islamic School. This study uses qualitative research methods and data collection techniques such as direct interviews with educators and observations in the learning process as well as documentation studies. Sources of data in this study are educators and students. The teaching activities of 4th graders at SD Cendekia Islamic School class IV have been carried out on a distance learning basis since the outbreak of covid-19 in Indonesia. The results of this research, conducted on fourth-grade students at SD Cendekia Islamic School, show that the learning activities carried out during the distance learning period were not optimal in terms of scientific approaches. Because, according to researchers, the use of a scientific approach, when face-to-face interaction with students is possible, is more efficient than its use in distance learning, which is the current situation. Hence, the researchers conclude that the study conducted during the distance learning process that utilized scientific approaches did not maximize strengthening curiosity as a trait. Researchers suggest that, in distance learning exercises, it is necessary to pay attention first to all components that can support the successful implementation of scientific approaches on the development of curiosity as a trait.
\end{abstract}

Keywords: Curiosity as a trait, scientific approach, distance learning.

\section{ABSTRAK}

Penelitian ini bertujuan untuk mengetahui strategi penguatan karakter rasa ingin tahu melalui pembelajaran saintifik pada peserta didik di SD Cendekia Islamic School kelas IV. Penelitian ini menggunakan metode kualitatif dengan teknik pengumpulan data berupa wawancara langsung kepada pendidik dan observasi dalam proses pembelajaran. Sumber data pada penelitian ini adalah pendidik dan peserta didik. Pembelajaran yang dilakukan di SD Cendekia Islamic School kelas IV dilakukan secara PJJ sejak adanya covid-19 di Indonesia. Berdasarkan hasil penelitian menunjukkan bahwa penguatan karakter rasa ingin tahu terhadap peserta didik dengan menggunakan pendekatan saintifik kurang optimal. Karena pada dasarnya penggunaan pendekatan saintifik saat tatap muka lebih besar peluang keberhasilannya dibandingkan dengan kegiatan PJJ seperti saat ini. Maka dari itu peneliti menyimpulkan bahwa pengimplementasian pendekatan saintifik dalam penguatan karakter rasa ingin tahu belum maksimal dilakukan. Peneliti 
menyarankan jika mengimplementasikan pendekatan saintifik dalam kegiatan PJJ harus diperhatikan terlebih dahulu segala komponen yang dapat menunjang dalam keberhasilan pengimplementasian pendekatan saintifik terhadap penguatan karakter rasa ingin tahu peserta didik tersebut.

Kata Kunci: Karakter rasa ingin tahu, saintifik, pembelajaran jarak jauh.

\section{A. Pendahuluan}

Pendidikan merupakan usaha sadar yang dilakukan oleh manusia atau sekelompok manusia untuk mempengaruhi masyarakat mencapai kehidupan yang lebih baik. Pendidikan lebih dari sekedar pengajaran yang dapat dilakukan di sekolah, tetapi pendidikan dapat pula sebagai suatu proses transfer ilmu, nilai dan pembentukan kepribadian/sikap individu secara sadar dan sengaja serta penuh tanggung jawab yang dilakukan oleh keluarga, masyarakat, dan pemerintah sehingga timbul interaksi dari berbagai pihak.

Usaha sadar serta terencana tersebut tentunya memiliki tujuan dalam pengubahan perilaku manusia untuk mempersiapkan di masa yang akan datang. Menurut John Dewey pendidikan sendiri merupakan salah satu proses diri untuk menemukan pembaharuan sebagai sebuah pengalaman (John Dewey, 2012). Pengalaman yang dimaksud tersebut yang dapat memberikan sebuah pembelajaran baru yang nantinya dapat terimplementasikan dalam kehidupannya bermasyarakat.

Dari pendidikan tersebut tentunya memiliki fungsi tersendiri dalam menciptakan perubahan yang ada pada diri manusia. Seperti menurut Umar Tirtaraharja (Haderani, 2017) yang dimana pendidikan memiliki fungsi yang diantaranya untuk mengajarkan tingkah laku dan untuk mempersiapkan individu dalam menghadapi

peranan-peranan tertentu nantinya. Sehubungan dengan fungsi ini pendidikan bertugas untuk mengajarkan berbagai macam pengetahuan, keterampilan dan keahlian dalam rangka mempersiapkan anak untuk pekerjaan-pekerjaan yang akan mendatang.

Proses pembelajaran tersebut tentunya terbentuk dari setiap aktivitas pembelajaran yang diberikan oleh pendidik kepada peserta didik. Dengan demikian pada proses pendidikan sekarang dalam 
pembelajarannya

sudah

menggunakan kurikulum 2013. Yang dimana kurikulum pendidikan sendiri dapat diartikan sebagai suatu bahan tertulis yang berisi uraian tentang program pendidikan suatu sekolah atau madrasah dari tahun ke tahun. Jika kita artikan lebih dalam lagi, kurikulum pendidikan merupakan sarana pengajaran di sekolah maupun di madrasah, sebagai sarana belajar peserta didik, dan sebagai pengajaran yang diperoleh peserta didik di sekolah maupun di madrasah (Soleh Hidayat, 2017: 20).

Tetapi pada kenyataannya, pada bulan maret 2020 virus Covid-19 memasuki Indonesia. Yang dimana hal ini mengakibatkan beberapa faktor terhambat terlebih dalam proses pendidikan. Proses pembelajaran dilakukan secara daring atau biasa disebut dengan Pembelajaran Jarak Jauh (PJJ). Tak terkecuali seperti yang dilakukan oleh SD Cendekia Islamic School ini. Selama virus Covid-19 ini pembelajaran dilakukan secara full daring. Hal ini mengakibatkan beberapa faktor yang menghambat pada proses perkembangan peserta didik itu sendiri selama proses pembelajaran berlangsung.
Dalam proses pembelajaran tentunya peserta didik harus memiliki rasa ingin tahu yang tinggi. Seperti yang kita ketahui bahwa setiap rancangan pembelajaran yang sudah disusun oleh pendidik pasti bertujuan untuk mencapai semua indikator pencapaian kompetensi materi yang telah ditentukan. Dalam hal ini tentunya perlu dukungan dari peserta didik itu sendiri yang harus memiliki rasa ingin tahu yang tinggi.

Rasa ingin tahu sendiri memiliki arti sebagai suatu keinginan untuk memperoleh informasi yang belum diketahuinya serta pengalaman sensori yang memotivasi sikap ynag ada pada diri individu untuk melakukan pencarian hal-hal baru. Rasa ingin tahu tersebut akan memberikan perasaan negatif ketika tidak terpenuhi, tetapi akan memberikan kepuasan ketika mendapatkan perolehan informasi yang diinginkan (Reio, 2018).

Berdasarkan hasil observasi yang dilakukan oleh peneliti, bahwa di SD Cendekia Islamic School khususnya pada kelas IV ini peserta didik kurang memiliki rasa ingin tahu salah satunya karena faktor pembelajaran yang dilakukan secara PJJ karena adanya virus Covid-19. 
Pembelajaran jarak jauh ini berdampak kepada proses perkembangan peserta didik yang menurun. Salah satunya karakter rasa ingin tahu yang perlahan mulai hilang dari peserta didik. Peserta didik cenderung lebih banyak mendengarkan semua penjelasan dari guru dibandingkan dengan lebih banyak bertanya terkait hal-hal yang sifatnyanya konkret dengan kehidupan peserta didik yang berhubungan dengan materi pembelajaran. Dengan begitu, peserta didik cenderung lebih pasif selama proses Pembelajaran Jarak Jauh (PJJ) ini.

Pada proses pembelajaran menggunakan kurikulum 2013 ini sudah tidak asing lagi dengan yang namanya pendekatan saintifik. Pendekatan saintifik ini muncul berbarengan dengan perubahan kurikulum 2013. Seperti yang kita ketahui bahwa pendekatan saintifik ini diciptakan untuk agar pembelajaran lebih interaktif yang dimana pada kurikulum 2013 ini proses pembelajaran sudah berpusat kepada peserta didik (Student Center).

Seperti halnya pada pembelajaran yang dilakukan di SD Cendekia Islamic School khususnya pada peserta didik di kelas IV. Pada saat peneliti melakukan observasi terkait hal ini, proses pembelajarn yang dilakukan di sekolah dasar swasta ini tetap menggunakan pendekatan saintifik. Yang dimana pendekatan saintik menurut Mastura (Siti Solihat, 2019) diartikan sebagai suatu pembelajaran yang menggunakan proses berpikir ilmiah yang di dalamnya mencakup kegiatan bertanya, mengamati, mengolah, menyajikan, dan menyimpulkan data. Pendekataan ini juga dapat dijadikan sebagai suatu jembatan untuk mengembangkan kreativitas, keterampilan bahkan sikap yang ada dalam diri peserta didik tersebut. Dalam proses pembelajaran terlebih dalam PJJ ini pendidik tentunya harus memiliki strategi khusus yang dapat diimplementasikan selama proses PJJ ini berlangsung.

Berdasarkan penjelasan diatas, peneliti tertarik untuk menggarap suatu

penelitian

mengimplementasikan pendekatan saintifik selama proses pembelajaran untuk melihat pengaruhnya terhadap penguatan karakter rasa ingin tahu peserta didik yang ada di kelas IV SD Cendekia Islamic School ini. Demikian, peneliti menentukan judul 
penelitian ini yaitu "Strategi

Penguatan Karakter Rasa Ingin Tahu

Peserta Didik Melalui Pembelajaran

Saintifik di SD Cendekia Islamic

School Kelas IV".

\section{B. Metode Penelitian}

Metode penelitian yang dilakukan pada penelitian ini yaitu metode deskriptif dengan menggunakan pendekatan kualitatif, metode penelitian deskriptif digunakan untuk memberi gambaran kenyataan yang ada, yang sedang berlangsung atau sudah terjadi selama proses penelitian. Penelitian deskriptif digunakan apabila tujuan penelitia terbatas pada penggambaran sebenarnya dari penemuan yang ada di lapangan. Penelitian ini dilakukan untuk mengetahui startegi penguatan karakter rasa ingin tahu pada pembelajaran saintifik di SD Cendekia Islamic School kelas IV. Dalam pengumpulan data atau interpretasi fakta, peneliti mengambil secara langsung pada proses pembelajaran kelas IV SD Cendekia Islamic School.

Sumber penelitian peneliti disini yaitu peserta didik kelas IV SD Cendekia Islamic School yang dimana untuk mendapatkan informasi terkait startegi penguatan karakter rasa ingin tahu pada pembelajaran saintifik di SD Cendekia Islamic School kelas IV. Selain peserta didik, sumber yang diambil pula dari guru kelas atau wali kelas kelas IV SD Cendekia Islamic Scool. Yang dimana informasi yang diberikan oleh guru ini mengenai kegiatan pembelajaran kelas peserta didik yang dilakukan dengan menggunakan pendekatan saintifik pada saat pembelajaran berlangsung.

Adapun teknik pengumpulan data yang dilakukan peneliti pada penelitian ini yaitu teknik wawancara langsung kepada walikelas kelas IV SD Cendekia Islamic School, observasi kegiatan pembelajaran peserta didik dan dokumentasi. Kegiatan pengumpulan data wawancara kepada walikelas dilakukan secara tatap muka langsung di SD Cendekia Islamic School dengan menggunakan protokol kesehatan yang ketat tetapi peneliti melakukan tanya jawab pula kepada walikelas melalui WhatsApp. Dan untuk kegiatan observasi kepada peserta didk dilakukan secara daring, karena pembelajaran yang dilakukan di SD ini masih online dengan 
menggunakan aplikasi GoogleMeet. Kemudian data yang telah peneliti peroleh ini dianalisis secara deskriptif.

\section{Hasil Penelitian dan Pembahasan}

Proses pembelajaran merupakan suatu bagian yang pasti akan dilewati oleh setiap manusia pada jenjang satuan pendidikan. Dalam proses pembelajaran tentunya banyak sekali harapan-harapan yang nantinya akan membentuk pribadi peserta didik. Seperti hal nya karakter rasa ingin tahu ini. Penguatan terhadap karakter rasa igin tahu ini dapat dilakukan oleh pendidik dengan menggunakan salah satu strategi pendekatan saintifik yang memiliki komponen dengan 5M (Mengamati, Menanya, Mencoba, Menalar dan Mengkomunikasikan).

Penelitian ini dilakukan di SD Cendekia Islamic School khususnya pada kelas IV. Teknik pengumpulan data yang dilakukan oleh peneliti itu dengan melakukan wawancara dengan pendidik secara langsung dan melakukan observasi terkait pembelajaran yang dilakukan.

Proses Pelaksanaan Pembelajaran dengan Menggunakan Pendekatan
Saintifik Terhadap Rasa Ingin Tahu Siswa

Dalam hal ini, sebelum melakukan proses kegiatan pembelajarannya tentunya pendidik menyusun Rancangan Proses Proses Pembelajaran (RPP) terlebih dahulu. Yang dimana RPP yang dibuat pun disesuaikan dengan mengunakan pendekatan saintifik. Tidak menutup kemungkinan bahwa dalam pelaksanaan proses PJJ menggunakan pendekatan saintifik ini sukar untuk diimplementasikan. Namun dalam hal ini, proses penguatan karakter rasa ingin tahu ini bisa dibangun salah satunya melalui pendekatan saintifik tersebut. Pendekatan saintifik sendiri didefinisikan sebagai proses pembelajaran yang dirancang dengan sedemikian rupa untuk membuat peserta didik aktif dalam belajar untuk menentukan konsep pembelajaran, mengidentifikasi suatu permasalahan, memecahkan permasalahan, merumuskan permasalahan, mengumpulkan data, menganalisis data, mengkomunikasikan suatu data dan membuat kesimpulan atas apa yang dipelajari (Sufairoh, 2016: 120). 
Berdasarkan

pengertian

pendekatan saintifik diatas ini menunjukan bahwa pembelajaran yang dilakukan di sekolah dengan menggunakan pendekatan saintifik seharusnya dilakukan secara luring atau tatap muka secara langsung, tetapi dikarenakan pandemi covid-19 masih ada maka pembelajaran dengan menggunakan pendekatan saintifik ini dikemas sedemikian rupa agar tercapat di pelaksanaan pembelajaran PJJ.

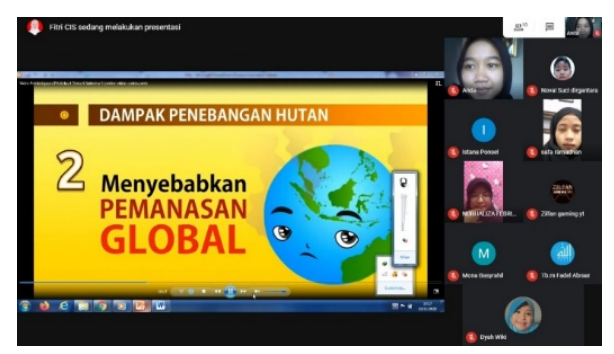

Gambar 1. Pelaksanaan pembelajaran

Dalam kegiatan pembelajaran PJJ ini, pendidik memaparkan materi pembelajaran menggunakan media pembelajaran Power Point, video pembelajaran, dan paint, yang dijadikan sebagai media pendukung dalam penyampaian materi pembelajaran. Yang dimana proses pembelajaran ini dilakukan secara PJJ maka dengan begitu media pembelajaran yang digunakan oleh pendidik tersebut pun berbasis digital.
Media pembelajaran yang digunakan dalam membantu penyampaian materi tersebut pun dirancang sedemikian rupa agar proses pembelajaran berjalan dengan interaktif dan peserta didik tergerak untuk menggali lebih dalam informasi terkait materi yang disampaikan oleh pendidik. Penggunaan media pembelajaran disini dikhususkan untuk menarik perhatian peserta didik terhadap materi yang akan disampaikan, dengan begitu peneliti bisa melihat apakah peserta didik di kelas IV SD Cendekia Islamic School ini tertarik dengan pembelajaran yang akan dilakukan.

Selain itu, penggunaan media pembelajaran pada saat pembelajaran saintifik ini membantu pendidik dalan terselenggaranya pembelajaran yang optimal. Yang dimana pada saat pembelajaran berlangsung, peserta didik dan pendidik dapat mengimplementasikan $5 \mathrm{M}$ dari komponen yang terdapat dalam pendekatan saintifik yaitu peserta didik dan pendidik dapat mengkomunikasikan dengan baik materi yang sedang dipelajari, melakukan kegiatan tanya jawab, mengamati media atau penjelasan yang disampaikan oleh pendidik, 
menalar materi yang sudah dipelajari serta melakukan percobaan terkait materi yang sedang dipelajarinya tersebut. Selain untuk menarik perhatian peserta didik, media pembelajaran pula membantu peserta didik dalam hal rasa ingin tahu.

Yang dimana pada saat pendidik menjelaskan terkait materi pembelajaran dengan menggunakan media pembelajaran baik itu Power Point, video pembelajaran, maupun paint ini peneliti melakukan observasi apakah peserta didik kelas IV ini muncul rasa ingin tahunya terhadap pembelajaran apakah hanya diam saja pada saat pembelajaran ini berlangsung. Seperti yang dijelaskan oleh Reio dan dikutip kembali oleh Steven Raharja, dkk (2018:154) mendefinisikan rasa ingin tahu sebagai suatu keinginan untuk memperoleh informasi yang belum diketahuinya serta pengalaman sensori yang memotivasi sikap yang ada pada diri individu untuk melakukan pencarian hal-hal baru. Rasa ingin tahu tersebut akan memberikan perasaan negatif ketika tidak terpenuhi, tetapi akan memberikan kepuasan ketika mendapatkan perolehan informasi yang diinginkan.
Hasil dari Pendekatan Saintifik Terhadap Rasa Ingin Tahu Siswa dalam Proses Pembelajaran

Dengan melalui proses pembelajaran menggunakan pendekatan saintifik tentunya semua bertujuan untuk meningkatkan hasil belajar peserta didik. Pendekatan saintifik ini dirancang pemerintah untuk mengembangkan nilai karakter yang ada pada setiap peserta didik. Pendekatan saintifik ini dirancang untuk melatih peserta didik berpikir ilmiah serta melatih untuk memiliki kemampuan menyelesaikan setiap permasalahan yang dihadapinya dan memiliki hasil belajar yang tinggi. Dalam hal ini, dengan pendekatan saintifik peserta didik diharapkan dapat mengembangkan 18 nilai karakter yang di milikinya dan salah satunya yaitu rasa ingin tahu. Hasil dari pembelajaran yang menggunakan pendekatan saintifik ini tentunya berdampak besar terhadap peserta didik dalam proses pembelajaran. Seharusnya dalam penerapan pendekatan saintifik ini, peserta didik menjadi lebih semangat mengikuti pembelajaran, menjadi lebih kreatif, menjadi lebih percaya diri, hingga memiliki rasa ingin tahu 
yang tinggi dalam menggali lebih dalam informasi terkait materi yang disampaikan dalam kegiatan pembelajaran.

Dengan menerapkan pendekatan ini, proses pembelajaran akan lebih berkesan serta bermakna bagi peserta didik, karena pendekatan ini mengajak peserta didik untuk memperoleh pengetahuan serta informasi baru secara mandiri yang bisa berasal dari mana saja, kapan saja, dan tidak bergantung pada informasi yang searah dari pendidik tersebut. Selain dapat menjadikan peserta didik yang lebih aktif dalam mengkonstruksi pengetahuan dan keterampilannya, juga dapat mendorong peserta didik dalam hal untuk melakukan penyelidikan guna menemukan fakta-fakta dari suatu fenomena atau kejadian yang dialami oleh setiap peserta didik (Efriana, 2014:9).

Pada kenyataannya, selama peneliti melakukan penelitian terhadap peserta didik kelas IV di SD Cendekia Islamic School ini, hasil yang di dapat peneliti bahwa ketika pendidik melakukan pembelajaran dengan menggunakan pendekatan saintifik, menurut peneliti hasil pembelajaran terhadap siswa ini belum maksimal dalam kegiatan PJJ ini. Hanya beberapa komponen pendekatan saintifik saja yang tercapai dalam kegiatan PJJ ini. Walaupun dengan diterapkan pendekatan saintifik ini memang diharapkannya agar peserta didik lebih aktif lagi, tetapi dalam hal ini pendidik juga mengungkapkan memang sedikit kesuliatan menerapkan pendekatan saintifik di kegiatan PJJ ini. Terbukti selama proses pembelajaran berlangsung siswa kelas IV ini yang hanya berjumlah 8 orang, ketika kegiatan pembelajaran ini hanya mengandalkan apa yang di perintahkan oleh pendidik serta hanya sebatas apa yang dipaparkan oleh pendidik. Yang peneliti lihat bahwa peserta didik ini kurang menunjukan kegiatan pembelajaran dengan menggunakan pendekatan saintifik, walaupun pendidik ini sudah mencoba menggunakan pendekatan tersebut dan menerapkan strategi pendukung lain dalam pembelajaran tersebut. Kurang lebih hanya 2-3 orang saja yang memiliki rasa keingin tahuan dalam pembelajaran ini serta memiliki semangat yang tinggi dalam pembelajaran walaupun dalam kondisi PJJ seperti ini. Beberapa 
orang peserta didik yang peneliti lihat ini ketika pembelajaran ada yang terlihat aktif dibanding temannya dan ada pula peserta didik yang ketika namanya disebutkan untuk memberikan pendapat dia selalu meninggalkan Room Google Meet tersebut. Dari situlah peneliti dapat lihat bahwa penerapan pendekatan saintifik ini belum terlaksana sepenuhnya jika dalam kegiatan PJJ seperti ini.

Selama kegiatan PJJ ini, semangat belajar peserta didik juga naik turun. Memang penggunaan media dalam pembelajaran ini sedikit membantu dalam proses pembelajaran ini. Seperti saat mata pelajaran IImu Pengetahuan Sosial (IPS), peserta didik telihat bersemangat menyimak video pembelajaran yang ditampilkan oleh pendidik, namun memang ketika pendidik meminta peserta didik tersebut untuk menyampaikan kembali/memberikan pendapat terkait video yang telah di cermatinya, peserta didik tersebut tidak bereaksi apapun. Mereka masih menunjukkan bahwa pembelajaran ini mengandalkan pendidik dalam penyampaian materinya. Dan hal lain ketika pendidik ini meminta untuk peserta didik berusaha fokus mengikuti pembelajaran ada saja peserta didik yang meyepelekan hal itu. Memang dalam kegiatan PJJ ini fokus siswa juga terbagi-bagi ketika dirumah. Tetapi dalam hal percaya diri, peserta didik ini cukup memiliki rasa percaya diri dalam menjawab soal-soal yang diberikan oleh pendidik. Hal ini dapat kita lihat pada bukti foto ketika peserta didik bersemangat untuk menjawab soal yang diberikan oleh pendidik.

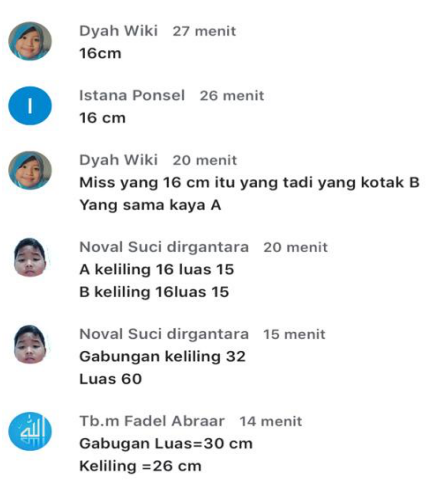

Gambar 2. Aktivitas

Menjawab Soal

Tentunya menurut peneliti, penggunaan pendekatan saintifik ini kurang berhasil dalam meningkatkan rasa ingin tahu siswa kelas IV di SD Cendekia Islamic School ini. Karena memang seperti yang peneliti jelaskan sebelumnya. Penerapan pendekatan tersebut dalam kegiatan PJJ ini memiliki kesulitan tersendiri, dan benar apa yang dikatakan pendidik tersebut selaku wali kelas, kelas IV 
bahwa besar kemungkinan penguatan rasa ingin tahu menggunggunakan pendekatan saintifik ini belum maksimal penerapannya kegiatan PJJ ini.

\section{Kesimpulan}

Dari hasil hasil penelitian strategi penguatan karakter rasa ingin tahu peserta didik menggunakan pendekatan saintifik di SD Cendekia Islamic School kelas IV, dapat disimpulkan bahwa : 1) Penggunaan pendekatan saintifik dalam proses penguatan karakter rasa ingin tahu di kelas IV dapat memberikan dampak pada keaktifan peserta didik namun pendekatan saintifik yang diimplementasikan belum maksimal dalam kegiatan PJJ. 2) Penggunaan media digital dalam kegiatan PJJ sangat membantu pendidik dalam penguatan karakter rasa ingin tahu menggunakan pendekatan saintifik. 3) kegiatan PJJ mengakibatkan peserta didik cenderung memiliki semangat belajar yang tidak stabil dan mengakibatkan pengimplemntasian pendekatan saintifik terhadap rasa ingin tahu kurang optimal.

Berdasarkan hasil penelitian yang telah dilaksanakan, terdapat rekomendasi yang dapat diberikan yaitu pendidik dapat menggunakan berbagai macam media pendukung yang bersifat digital dan interaktif untuk membantu dalam penguatan karakter rasa ingin tahu menggunakan pendekatan saintifik selama kegiatan PJJ. Peneliti selanjutnya menyarakan jika ingin mengimplementasikan pendekatan saintifik dalam kegiatan PJJ harus benar-benar diperhatikan terlebih dahulu segala komponen yang dapat menunjang dalam keberhasilan pengimplementasian pendekatan saintifik terhadap rasa ingin tahu peserta didik.

\section{DAFTAR PUSTAKA}

Hidayat, S. (2017). Pengembangan Guru Profesional. Bandung: PT Remaja Rodakarya.

Hidayat, S. (2017). Pengembangan Kurikulum Baru. Bandung: PT Remaja Rosdakarya.

Kodir, A. (2018). Manajemen Pembelajaran Saintifik Kurikulum 2013 Pembelajaran Berpusat Pada Siswa. Bandung: CV Pustaka Ceria. 
Didaktik : Jurnal IImiah FKIP Universitas Mandiri ISSN Cetak : 2477-5673 ISSN Online : 2614-722X

Volume 07 Nomor 02, Desember 2021

Raharja, S,.dkk. (2018). Mengukur Rasa Ingin Tahu Siswa. JBSBP. 14(2), 151-164.
S, Tatang. (2012). IImu Pendidikan. Bandung: CV Pustaka Setia. 